\title{
REALIZED GENETIC GAIN AND SEED SOURCE $X$ SITE INTERACTION ON STAND VOLUME PRODUCTIVITY OF ACACIA MANGIUM
}

\author{
Arif Nirsatmanto ${ }^{1 *}$, Teguh Setyaji ${ }^{1}$ and Reny Setyo Wahyuningtyas ${ }^{2}$
}

Received: 3 July 2013, Accepted: 3 March 2014

\begin{abstract}
Following the results of the comprehensive tree improvement programs for Acacia mangium, it is necessary to estimate the real amount of genetic improvement and to develop an improved seed deployment strategy. This study was aimed to verify realized genetic gain on stand volume productivity attained by the firstgeneration Seedling Seed Orchards (SSO) of A. mangium and to identify the magnitude of seed sources $\mathrm{x}$ site interaction as a basis for improved seed deployment. Seeds from five SSOs were tested together with seeds from seed stand in genetic gain trials which were established in South Kalimantan and Central Java. Realized gains were calculated from the percentage improvement of respective SSOs compared with seed stand at two and four years of age. Seed source $\mathrm{x}$ site interaction was investigated through analysis across the two sites. Results of the study showed that trees derived from the five SSOs produced better stand volume than those from seed stand. At four years of age, stand volume of the best SSO reached around $127 \mathrm{~m}^{3} / \mathrm{ha}$ in South Kalimantan and $84 \mathrm{~m}^{3} /$ ha in Central Java. Realized genetic gain were around $66 \%$ at two years and $59 \%$ at four years in South Kalimantan, and around $136 \%$ at two years and $81 \%$ at four years in Central Java. Seed source $\mathrm{x}$ site interaction was not significantly different indicating superiority of improved seed were consistent across the two sites with the average realized gain ranging from $18 \%$ to $79 \%$ and $24 \%$ to $62 \%$ at two and four years, respectively. The best three SSOs were SSO-1 located in Pleihari-South Kalimantan, SSO-2 in Pendopo-South Sumatra and SSO-5 in Wonogiri-Central Java, all of which originated from Papua New Guinea provenances. Improved seed from the orchards could be used at plantation sites without any significant change of the order in their superiority for stand volume productivity.
\end{abstract}

Keywords: Acacia mangium, genetic gain trial, realized genetic gain, seedling seed orchard, stand volume

\begin{abstract}
ABSTRAK
Studi ini bertujuan untuk mengetahui besarnya perbaikan genetik aktual terhadap produktifitas volume tegakan dan interaksi sumber benih x lokasi pertanaman. Benih unggul A. mangium dari lima kebun benih diuji bersama benih dari tegakan benih di plot uji perbaikan genetik di Kalimantan Selatan dan Jawa Tengah. Hasil penelitian menunjukkan bahwa benih unggul dari kebun benih memiliki produktivitas volume tegakan yang lebih tinggi dibandingkan benih kontrol dari tegakan benih. Tingkat perbaikan genetik aktual di Kalimantan Selatan mencapai 66\% umur dua tahun dan 59\% umur empat tahun, sedangkan di Jawa Tengah mencapai $136 \%$ umur dua tahun dan $81 \%$ umur empat tahun. Interaksi sumber benih x lokasi tidak menunjukkan pengaruh yang nyata dan superioritas benih unggul stabil dikedua lokasi. Benih unggul dari lima kebun benih yang diuji dapat digunakan untuk pembangunan pertanaman di Kalimantan Selatan dan Jawa Tengah tanpa ada penurunan superioritas terhadap produktifitas volume tegakan yang dihasilkan.
\end{abstract}

Kata kunci: Acacia mangium, uji perbaikan genetik, perbaikan genetik riil, kebun benih, volume tegakan

\footnotetext{
${ }^{1}$ Center for Forest Biotechnology and Tree Improvement, Jl. Palagan Tentara Pelajar Km. 15, Purwobinangun, Yogyakarta 55582 - Indonesia

${ }^{2}$ Banjarbaru Forestry Research Institute, Jl Ahmad Yani Km.28,7 Landasan Ulin, Banjarbaru, South Kalimantan 70721 - Indonesia

*Corresponding Author: arif_nirz@yahoo.com
} 


\section{INTRODUCTION}

Establishment of Acacia mangium plantations in Indonesia in the early years had been using seeds collected from seed stand. The oldest seed stand of $A$. mangium in Indonesia was established in 1979 at Subanjeriji, South Sumatra, and used combination of bulk seeds from Queensland and Indonesian provenances (Werren, 1991). This seed stand is well known as the land race of Subanjeriji, and its seed production had been widely used in the establishment of the first rotation $A$. mangium plantations. The use of seeds collected from such kind of seed source was commonly practiced in the beginning of the plantation programs before permanent seed orchards became available (Zobel and Talbert, 1984).

Due to the growing importance of $A$. mangium in large scale plantation programs, the demand of genetically improved seeds of this species was increasing to improve the productivity of the plantations. In order to fulfill the demand, first-generation seedling seed orchards of $A$. mangium were established in some regions in Indonesia under a comprehensive tree improvement program, such as in South Kalimantan, South Sumatra, West Kalimantan and Central Java (Hashimoto et al., 1996). The seedling seed orchard was initially established as a progeny test using families collected from superior provenances in Papua New Guinea and Far North Queensland. In 2000, the selection procedures have completely finished, and the orchards were in the stage of production of improved seeds ready for plantation.

Studies designed specifically to estimate realized genetic gain will allow the tree breeder to show what has actually been achieved through selection and breeding (Zobel and Talbert, 1984). Such studies can be implemented by establishing genetic gain trials, where the improved seeds are tested against the unimproved seeds in a plot trial with the same silvicultural practices. Establishing genetic gain trials will be required if we want to be able to confidently obtain realized genetic gain from improved plantation (St. Clair, 1993).
Genetic gain trials can be established and replicated in several plantation locations, and thus it will be useful to identify the magnitude of seed source $\mathrm{x}$ site interaction which is important for the development of a genetically improved seed deployment strategy. This is needed because often a strong genotype $\mathrm{x}$ environment interaction for growth traits restricts the possible gains when one population is destined for use over wide areas of plantation (Zobel and Talbert, 1984). In addition, genetic gain is better to be presented as an expected amount of improvement in the form of volume productivity per unit area. This is because single tree volume is not always a good indicator to measure the potential of improvement in volume productivity.

Studies on realized genetic gains by firstgeneration tree improvement in forest tree species have been done for several pine species, for example, $16 \%-18 \%$ increase in stand volume at 10 years age (Matziris, 1974) and 7\%$12 \%$ at rotation age ( $\mathrm{Li}$ et al., 2000) for loblolly pine; $32 \%$ increase in individual stem volume for black pine (Matziris, 2005). In the case of tropical forest species, Luangviriyasaeng and Pinyopusarerk (2002) reported outstanding growth and form trait of improved families of A. auriculiformis at 36-40 months. With regard to $A$. mangium, although Nirsatmanto et al. (2004) has reported the realized genetic gain based on the one year age data observed in second-generation of seed orchard: increased around 3\%, $5 \%$ and $4 \%$ for height, diamater and stem straightness respectively, the realized genetic gain was not yet verified in genetic gain trial. Therefore, the objective of this study is to verify the realized genetic gain for stand volume productivity attained by the first-generation seedling seed orchards of $A$. mangium in two genetic gain trials located in Central Java and South Kalimantan. As a basis to develop an improved seed deployment strategy, the effect and the magnitude of seed sources $\mathrm{x}$ site interaction were also investigated. 


\section{MATERIAL AND METHOD}

\section{A. Genetic Gain Trials}

Following a comprehensive tree improvement program for $A$. mangium, three genetic gain trials were established in Central Java $\left(7^{\circ} 32^{\prime} \mathrm{S}\right.$ and $\left.110^{\circ} 41^{\prime} \mathrm{E}\right)$, South Sumatra $\left(3^{\circ} 15^{\prime} \mathrm{S}\right.$ and $\left.103^{\circ} 50^{\prime} \mathrm{E}\right)$, and South Kalimantan $\left(3^{\circ} 30^{\prime} \mathrm{S}\right.$ and $\left.115^{\circ} 0^{\prime} \mathrm{E}\right)$ (see Table 1$)$. The last two locations represent the regions with large scale operational plantations of $A$. mangium in Indonesia. The design of all genetic gain trials was similar using a randomized complete block design which was laid out as 100 trees in square plots $(10 \times 10$ trees) of $4-5$ replications with a spacing of $4 \times 2 \mathrm{~m}$. High mortality occurred in the trial in South Sumatera due to fire, thus this trial was excluded from the analysis. At four years of age, two replications in the trial in South Kalimantan was also destroyed by fire, thus at this age only three out of five replications from this trial were used for the analysis.

Basically, the genetic gain trials consisted of the same set of a mix open pollinated seeds collected from eight seed sources. However, for the purpose of this study, only six of the seed sources were used for the analysis: five seedling seed orchards (SSO) and one seed stand as the control (Table 2). The five seedling seed orchards (referred to as SSO-1, SSO-2, SSO-3, SSO-4, SSO-5) were established using family originating from Papua New Guinea and Queensland-Australia provenances as part of a comprehensive breeding program for $A$. mangium (Hashimoto et al., 1996). While one control was the seed stand from the local land race of Subanjeriji (Werren, 1991).

\section{B. Measurement and Statistical Analysis}

Investigation was done by analyzing stand volume productivity at two and four years of age. Individual stem volume was derived from the volume equation (Inose et al., 1992) using height and diameter at breast height (dbh):

$$
\mathrm{V}=0.000058806 \times \mathrm{D}^{1.71772} \times \mathrm{H}^{1.0809}
$$

To get an accurate observation, only the inner 64 trees $(8 \times 8$ trees) in each square plot were measured to stimulate the competition that would occur between individual trees of the same seed source. The stand volume on each plot was calculated by summing up the individual stem volumes of all surviving trees in each plot, which was then expressed as stand volume productivity per hectare $\left(\mathrm{m}^{3} / \mathrm{ha}\right)$ using the following equation:

$$
\text { Stand Volume per Hectare }=\frac{\text { stand volume on plot }}{\text { area of plot in square meter }} \times 10000 \ldots . . . . . . . . . . .(2)
$$

Analysis of variance was made at each site as well as across the two sites with the following linear equations (Hai et al., 2008):

$$
\begin{array}{r}
Y_{i j}=\boldsymbol{\mu}+B_{i}+S_{j}+\boldsymbol{e}_{i j} \quad \text { (for each site) ...........(3) } \\
Y_{i j k}=\mu+L_{i}+B / L_{i j}+S_{\mathrm{k}}+S_{*} L_{i k+} e_{i j k} \text { (for across sites) ..........(4) }
\end{array}
$$

Where, $\mu=$ population mean, $B_{i}=$ the ith replication effect, $S_{j}=$ the jth seed source effect, $L_{i}=$ the ith site effect, $B / L_{i j}=$ the jth replication effect in the ith site, $S_{k}=$ the keth seed source effect, $S^{*} L_{i k}=$ the effect of seed source $\times$ site interaction, eijand eijk = experimental error associated with yij and yijk, respectively.

The realized genetic gains were calculated as differences between the respective seedling seed orchard and the seed stand, all of which were the least square estimates of the linear model given in Equations 3 and 4. Then the relative gain was calculated as a percentage rate of the gain to the average seed stand.

\section{RESULT AND DISCUSSION}

\section{A. Survival Rate and Stand Volume}

The average number of surviving trees varied slightly among seed sources as indicated by the different average number of observations per plot (Table 3). Except SSO-4 in genetic gain trial in Central Java, which had the smallest number of observation (survival rate around $70 \%$ ), the average number of surviving trees per plot in each seed source at both ages and sites were more than 51 (survival rate was ranging from 
$80 \%$ to $97 \%$ ). Difference in survival by seed sources over the two ages was small (less than $3 \%$ ). In South Kalimantan, the data used for analysis at four years was only from three out of five replications (two damaged replications with low survival rates were excluded). As a result, the average number of trees per plot at four years increased from that at the two years age. The high survival rate would be sufficient to ensure an accurate comparison among the tested seed sources to examine the realized genetic gain and seed source $\mathrm{x}$ site interactions for stand volume productivity in genetic gain trial.

Stand volume productivity of genetic gain trial in South Kalimantan was much better than that in Central Java. The average stand volume in South Kalimantan was $18.62 \mathrm{~m}^{3} /$ ha at two years and $108.43 \mathrm{~m}^{3} /$ ha at four years, while the corresponding stand volume in Central Java was $6.76 \mathrm{~m}^{3} / \mathrm{h}$ at two years age and $72.53 \mathrm{~m}^{3}$ / ha at four years age (Table 3 ). The differences observed here are possibly associated with climatic characteristic, whereby rainfall in Central Java is lower than in South Kalimantan: $1,878 \mathrm{~mm}$ in Central Java and 2,043 $\mathrm{mm}$ in South Kalimantan (see Table 1). The natural distribution of this species can be found in areas with a range of rainfall from $1446 \mathrm{~mm}$ to $2970 \mathrm{~mm}$ and can tolerate a minimum annual rainfall of $1000 \mathrm{~mm}$. A. mangium has performed well in site with higher annual rainfall. In addition, the growth seems to slow or cease in response to the combination of low rainfall and temperature (Mackey, 1996). Another reason might be due to the differences in the geographic coordinates of the sites, where the latitude of test plantations decreases from $7^{\circ} 32^{\prime}$ $\mathrm{S}$ in Central Java to $3^{\circ} 30^{\prime} \mathrm{S}$ in South Kalimantan. The same trend of faster early growth with decreasing latitude for $A$. mangium was also observed in trials and operational plantations in Vietnam (Kha, 2011) and in provenance trial in many tropical countries (Harwood and Williams, 1991). Besides the climate factor in general, soils property is also another important factor of plantation productivity. Despite $A$. mangium tolerates to the soil with low fertility, its growth more pronounced in a site with red and well drained soil properties such as Podzols, the similar type of soil as in the site of South Kalimantan in this study (Table. 1). Moreover, most of $A$. mangium plantation in Indonesia were also established in the regions dominated by the type soil of Podzols (Hardiyanto and Wicaksono, 2008; Golani et al., 2009).

Trees planted using seed sources from five seedling seed orchards outperformed those from seed stand (Table 3). Stand volume from the five orchards in genetic gain trial in Central Java exceeded $5 \mathrm{~m}^{3} / \mathrm{ha}$ and $60 \mathrm{~m}^{3} /$ ha at two and four years respectively, and those in South Kalimantan exceeded $15 \mathrm{~m}^{3} / \mathrm{ha}$ and $90 \mathrm{~m}^{3} / \mathrm{ha}$ at two and four years respectively. While the corresponding stand volume of the control seed source from seed stand at respective ages and sites were less than the observed values from the seedling seed orchards. Except at two years in Central Java, analysis of variance revealed that stand volume among seed sources

Table 1. Site location and experimental design of the genetic gain trail

\begin{tabular}{lcccccc}
\hline $\begin{array}{c}\text { Site location } \\
\text { (Latitude, Longitude) }\end{array}$ & $\begin{array}{c}\text { Altitude } \\
(\mathrm{m})\end{array}$ & $\begin{array}{c}\text { Mean annual } \\
\text { rainfall }(\mathrm{mm})\end{array}$ & $\begin{array}{c}\text { Temp. } \\
\text { Max. } / \text { Min. } \\
\left({ }^{\circ} \mathrm{C}\right)\end{array}$ & Soil type & Planting & Design \\
\hline $\begin{array}{l}\text { Central Java } \\
\left(7^{\circ} 32^{\prime} \mathrm{S} \text { and } 110^{\circ} 41^{\prime} \mathrm{E}\right)\end{array}$ & 141 & 1,878 & $33.23 / 21.9$ & Vertisols & 2002 & RCBD $/ 4$ replications \\
$\begin{array}{l}\text { South Sumatra } \\
\left(3^{\circ} 15^{\prime} \mathrm{S} \text { and } 103^{\circ} 50^{\prime} \mathrm{E}\right)\end{array}$ & 130 & 2,781 & $33 / 24$ & Podzolls & 2002 & RCBD $/ 4$ replications \\
$\begin{array}{l}\text { South Kalimantan } \\
\left(3^{\circ} 30^{\prime} \mathrm{S} \text { and } 115^{\circ} 0^{\prime} \mathrm{E}\right)\end{array}$ & 150 & 2,043 & $33.7 / 26.2$ & Podzolls & 2002 & RCBD $/ 5$ replications \\
\hline
\end{tabular}

$\mathrm{RCBD}=$ Randomized Complete Block Design 
Table 2. Six seed sources with different genetic levels and original provenances tested in genetic gain trial

\begin{tabular}{|c|c|c|c|c|}
\hline No. & Seed source & Location & $\begin{array}{l}\text { Latitude, Longitude, } \\
\text { (Elevation) }\end{array}$ & $\begin{array}{l}\text { Location of original } \\
\text { provenance }\end{array}$ \\
\hline 1. & SSO-1 & $\begin{array}{l}\text { Pleihari- } \\
\text { South Kalimantan }\end{array}$ & $\begin{array}{l}3^{\circ} 58^{\prime} \mathrm{S} \text { and } 114^{\circ} 37^{\prime} \mathrm{E} \\
(15 \mathrm{~m})\end{array}$ & $\begin{array}{l}\text { Dimissisi, PNG } \\
\text { Derideri E Morehead, PNG } \\
\text { Gubam NE Morehead, PNG } \\
\text { Bimadebun, PNG } \\
\text { Arufi Village, PNG } \\
\text { Boite NE Morehead, PNG }\end{array}$ \\
\hline 2. & SSO-2 & $\begin{array}{l}\text { Pendopo- } \\
\text { South Sumatra }\end{array}$ & $\begin{array}{l}3^{\circ} 31^{\prime} \mathrm{S} \text { and } 103^{\circ} 48^{\prime} \mathrm{E} \\
(80 \mathrm{~m})\end{array}$ & $\begin{array}{l}\text { Oriomo, PNG } \\
\text { Wipim, PNG } \\
\text { Kini, PNG }\end{array}$ \\
\hline 3. & $\mathrm{SSO}-3$ & $\begin{array}{l}\text { Pleihari- } \\
\text { South Kalimantan }\end{array}$ & $\begin{array}{l}3^{\circ} 58^{\prime} \mathrm{S} \text { and } 114^{\circ} 37^{\prime} \mathrm{E} \\
(15 \mathrm{~m})\end{array}$ & $\begin{array}{l}\text { Claudie River, FNQ } \\
135 \mathrm{~K} \text { N, FNQ }\end{array}$ \\
\hline 4. & $\mathrm{SSO}-4$ & $\begin{array}{l}\text { Pendopo- } \\
\text { South Sumatra }\end{array}$ & $\begin{array}{l}3^{\circ} 31^{\prime} \mathrm{S} \text { and } 103^{\circ} 48^{\prime} \mathrm{E} \\
(80 \mathrm{~m})\end{array}$ & $\begin{array}{l}\text { Pascoe River, FNQ } \\
\text { Claudie River, FNQ } \\
\text { Cassowary CK, FNQ }\end{array}$ \\
\hline 5. & SSO-5 & $\begin{array}{l}\text { Wonogiri- } \\
\text { Central Java }\end{array}$ & $\begin{array}{l}7^{\circ} 32^{\prime} \mathrm{S} \text { and } 110^{\circ} 41^{\prime} \mathrm{E} \\
(141 \mathrm{~m})\end{array}$ & $\mathrm{PNG}^{(*)}, \mathrm{FNQ}^{(* *)}$ \\
\hline 6. & Seed Stand & $\begin{array}{l}\text { Subanjeriji- } \\
\text { South Sumatra }\end{array}$ & $\begin{array}{l}3^{\circ} 05^{\prime} \mathrm{S} \text { and } 104^{\circ} 25^{\prime} \mathrm{E} \\
(80 \mathrm{~m})\end{array}$ & $\begin{array}{l}\text { Queensland (bulk) } \\
\text { IND (bulk) }\end{array}$ \\
\hline
\end{tabular}

PNG=Papua New Guinea; FNQ=Far North Queensland; IND=Indonesia

$\mathrm{SSO}=$ Seedling Seed Orchard

*) same as in seed source no.1, 2

**) same as in seed source no. 3, 4

Table 3. Average stand volume ( $\mathrm{m}^{3} / \mathrm{ha}$ ) and realized genetic gain $(\%)$ at two ages of measurements in genetic gain trial of Acacia mangium

\begin{tabular}{|c|c|c|c|c|c|c|c|c|}
\hline \multirow{3}{*}{ Seed source a) } & \multicolumn{4}{|c|}{2 years age } & \multicolumn{4}{|c|}{4 years age } \\
\hline & \multicolumn{2}{|c|}{ Central Java } & \multicolumn{2}{|c|}{ South Kalimantan } & \multicolumn{2}{|c|}{ Central Java } & \multicolumn{2}{|c|}{ South Kalimantan } \\
\hline & $\mathrm{N}$ & Volume & $\mathrm{N}^{\mathrm{b})}$ & Volume & $\mathrm{N}$ & Volume & $\mathrm{N}^{\mathrm{c})}$ & Volume \\
\hline SSO-1 & 55 & $7.29(+83)$ & 59 & $19.92(+46)$ & 55 & $74.36(+57)$ & 62 & $127.79(+59)$ \\
\hline SSO-2 & 58 & $9.42(+136)$ & 58 & $22.61(+66)$ & 56 & $85.89(+81)$ & 60 & $118.41(+47)$ \\
\hline $\mathrm{SSO}-3$ & 55 & $6.80(+71)$ & 59 & $18.40(+35)$ & 55 & $78.24(+65)$ & 61 & $111.80(+39)$ \\
\hline SSO-4 & 48 & $5.70(+43)$ & 56 & $15.36(+13)$ & 46 & $64.48(+36)$ & 60 & $92.01(+14)$ \\
\hline SSO-5 & 55 & $7.39(+86)$ & 59 & $21.76(+59)$ & 54 & $84.88(+80)$ & 60 & $120.02(+49)$ \\
\hline Seed Stand & 53 & 3.98 & 55 & 13.65 & 51 & 47.34 & 57 & 80.57 \\
\hline Grand Mean & 54 & 6.76 & 57 & 18.62 & 52 & 72.53 & 60 & 108.43 \\
\hline
\end{tabular}

$\mathrm{N}=$ average number of observation per plot

a) Seed sources as described in Table 2 .

b) number of observation based on five replications

c) number of observation based on three replications only or excluding two damaged replications

Value in parenthesis is realized genetic gain (\%)

were significantly different at both ages and sites (Table 4). Separation the means showed that the significant differences among seed sources were mainly a result of differences between the improved seeds from seedling seed orchards and the unimproved seeds from seed stand (Table 3). This result indicated that the improved seeds performed better than the 
Table 4. Degree of freedom and mean square values for each component of stand volume at two ages of measurements in genetic gain trial of Acacia mangium analyzed in each site using Equation(3).

\begin{tabular}{|c|c|c|c|c|}
\hline \multirow{2}{*}{ Source of variation } & \multicolumn{2}{|c|}{2 years volume } & \multicolumn{2}{|c|}{4 years volume } \\
\hline & $d f$ & Mean square & $d f$ & Mean square \\
\hline \multicolumn{5}{|l|}{ Central Java } \\
\hline Replication & 3 & 22.8797 & 3 & 284.9613 \\
\hline Seed source & 5 & $13.2633 \mathrm{~ns}$ & 5 & $853.0961 * *$ \\
\hline Error & 15 & 4.7358 & 15 & 173.0243 \\
\hline \multicolumn{5}{|l|}{ South Kalimantan } \\
\hline Replication & 4 & 58.2914 & 2 & 1614.3415 \\
\hline Seed source & 5 & $62.8200 * *$ & 5 & $999.2511^{* *}$ \\
\hline Error & 20 & 14.0269 & 10 & 172.7574 \\
\hline
\end{tabular}

**Significant at the $1 \%$ level, ns not significant

Table 5. Degree of freedom and mean square values for each component of stand volume at two ages of measurements in genetic gain trial of Acacia mangium analyzed across the two sites using Equation(4).

\begin{tabular}{lccrrrr}
\hline \multirow{2}{*}{ Source of variation } & \multicolumn{2}{c}{2 years volume } & & \multicolumn{2}{c}{4 years volume } \\
\cline { 2 - 3 } \cline { 6 - 7 } & $d f$ & Mean square & & $d f$ & Mean square \\
\hline Site & 1 & 1873.2697 ** & & 1 & $13257.7816^{* *}$ \\
Replication (site) & 7 & 43.1150 ** & & 5 & $816.7134^{* *}$ \\
Seed Source & 5 & 67.9251 ** & & 5 & $1714.5543^{* *}$ \\
Seed source x Site & 5 & 8.1583 ns & & 5 & 137.7930 ns \\
Error & 35 & 15.5567 & & 25 & 172.9175 \\
\hline
\end{tabular}

**Significant at the $1 \%$ level, ns not significant

control from unimproved seed regarding stand volume. Less inter-trees competition due to a slower growth in Central Java at two years probably reduced the magnitude of variance in seed sources level. As a result, stand volume among seed sources in such situation tends not to be significantly different.

Among the five seedling seed orchards, SSO2 was ranked first for stand volume in Central Java at both ages $\left(9.42 \mathrm{~m}^{3} / \mathrm{ha}\right.$ and $85.89 \mathrm{~m}^{3} /$ ha at two and four years, respectively), followed by the second ranked SSO-5 $\left(7.39 \mathrm{~m}^{3} / \mathrm{ha}\right.$ and $84.88 \mathrm{~m}^{3} /$ ha at two and four years, respectively), while SSO-3 and SSO-1 was an intermediate. In South Kalimantan, SSO-2 was also ranked first at two years $\left(22.61 \mathrm{~m}^{3} / \mathrm{ha}\right)$, but it was replaced by SSO-1 at four years $\left(127.79 \mathrm{~m}^{3} / \mathrm{ha}\right)$. The superiority of SSO-1 over SSO-2 at four years in South Kalimantan is probably due to the effect of the distance between seed source location and planting site. SSO-1 was located close to the trial site in South Kalimantan (50 $\mathrm{km}$ away) with probably more adaptive stand development at the trial site condition, while SSO-2 was located in South Sumatra (Table 2). The same as in Central Java, SSO-5 was second ranked at both ages $\left(21.76 \mathrm{~m}^{3} / \mathrm{ha}\right.$ and 120.02 $\mathrm{m}^{3} / \mathrm{ha}$ ). While SSO-4 performed poorest in stand volume productivity over both sites and ages. 
Table 6. Average stand volume across the two sites of genetic gain trial of Acacia mangium at two ages of measurements, followed by the ranking order

\begin{tabular}{ccccccc}
\hline \multirow{2}{*}{ Seed source } & \multicolumn{2}{c}{2 years volume } & & \multicolumn{2}{c}{ 4 years volume } \\
\cline { 2 - 3 } \cline { 6 - 7 } & Average $\left(\mathrm{m}^{3} / \mathrm{ha}\right)$ & Rank & & Average $\left(\mathrm{m}^{3} / \mathrm{ha}\right)$ & Rank \\
\hline SSO-1 & $14.30 a b c$ & 3 & & $97.26 a b$ & 3 \\
SSO-2 & $16.75 a$ & 1 & & $99.83 a b$ & 2 \\
SSO-3 & $13.25 b c$ & 4 & & $92.62 a b$ & 4 \\
SSO-4 & $11.07 c d$ & 5 & & $76.28 b$ & 5 \\
SSO-5 & $15.38 a b$ & 2 & & $99.94 a$ & 1 \\
Seed Stand & $9.35 d$ & 6 & & $61.58 c$ & 6 \\
\hline
\end{tabular}

Averages with the same letter in respective year indicate they are not significantly different at the $1 \%$ level

The superiority of SSO-1, SSO-2 and SSO5 over SSO-3 and SSO-4 might be mainly due to the effect of provenances. This is because the first three superior seedling seed orchards as described above mostly consisted of families from Papua New Guinea (PNG) provenances, while the other two seedling seed orchards consisted of families from Far North Queensland (FNQ)-Australia (Table 1). The superiority of PNG provenances as resulted in this study was in agreement with the report of previous provenance trials ( Harwood and William, 1991; Kari et al., 1996).

Absolute stand volume productivity in this study seemed lower as compared to the study reported by Otsamo et al., (1996). In a previous study, mean annual increment (MAI) of stand volume at 41 months age in South Kalimantan reached around $39 \mathrm{~m}^{3} / \mathrm{ha} / \mathrm{yr}$ and $28 \mathrm{~m}^{3} / \mathrm{ha} / \mathrm{yr}$ for PNG and FNQ provenances, respectively. The corresponding MAI in the present study at 4 years was around $30 \mathrm{~m}^{3} / \mathrm{ha} / \mathrm{yr}$ and $25 \mathrm{~m}^{3} /$ ha/yr for PNG and FNQ, respectively. This discrepancy is probably due to the differences in site preparation and the practices of singling multi-stemmed trees. In a previous study, the trial plots were plowed twice which was recognized as the best method to support the initial growth in Imperata cylindrica grassland area (Otsamo, et al., 1995), while in the present study the preparation of the trial site was made manually, that is clear-felling followed by burning. The singling practiced in the present study was also a source for reducing the stand volume. Otsamo et al. (1996) has reported a statistical difference between singling and control (no singling), in which MAI of the singled tree population was only $71 \%$ of that of the control.

\section{B. Realized Genetic Gain}

Superiority of the five seedling seed orchards over the seed stands resulted realized genetic gains for stand volume in the two sites which ranged from $13 \%$ to $136 \%$ at two years of age and $14 \%$ to $81 \%$ at four years of age (Table 3 ). In general, realized genetic gain in Central Java was higher than in South Kalimantan. Among both ages, the realized genetic gain at two years was generally higher than that at four years. These trends were probably due to the effect of increasing inter-tree competition from more rapid stand development, either attributable to good site quality or older age, which then tend to reduce the amount of genetic gain. Site in Central Java was less productive as compared to South Kalimantan, as shown by the slower growth of the trees (Table 3), which then indicated that the inter-tree competition in Central Java was less intense compared to South Kalimantan. Eldridge (1982) has reported a 
small genetic gain in productive site indicating the decreasing genetic gains with increasing stand development and competition.

Consistent with the superiority in absolute stand volume, realized genetic gain of seedling seed orchards originating mostly from PNG (SSO-1, SSO-2, SSO-5) were higher than those from FNQ provenances (SSO-3, SSO4). At two years, realized genetic gains ranged from $35 \%$ to $136 \%$ for the orchards of PNG provenances, and from $13 \%$ to $71 \%$ for the orchards of FNQ, while at four years the gains ranged from $39 \%$ to $81 \%$ and from $14 \%$ to $65 \%$ for the PNG and FNQ, respectively. SSO-2 which consisted of Oriomo, Wipim and Kini region of PNG provenances (see Table 1) showed the highest realized genetic gain in Central Java: $136 \%$ increase at two years age and $66 \%$ at four years. A. mangium from Oriomo region was recognized as the most productive of the PNG provenances (Harwood and Williams, 1991, Kari et al., 1996). While in South Kalimantan, the gain of SSO-2 was the highest at two years $(81 \%)$, but it was replaced by SSO1 at four years $(59 \%)$. Similar to the absolute stand volume, SSO-4 has produced the poorest realized genetic gain among the seedling seed orchards at both ages and sites, which ranged only from 36\% to 43\% in Central Java and 13\% to $14 \%$ in South Kalimantan. However, the data used in this study was collected at half rotation age (rotation age assumed to be 8 years) and the actual genetic gain might become smaller amount when the stand is getting older. This is because the amount genetic gain tends to be reduced as the stand development is progressing (Zobel and Talbert, 1984).

By considering the fact that the stand volume is a function of height, diameter and stem form, the amount of realized genetic gains in this study seemed to be greater than the gain confirmed in 1 year's measurement of secondgeneration seedling seed orchards as reported by Nirsatmanto et al. (2004). In a previous study, the realized gain which was calculated as percentage increase of family from selected plus trees in the first-generation orchards to the newly added infused family were around $3 \%, 5 \%$, and $4 \%$ for height, dbh, and stem straightness, respectively. This discrepancy might be mostly due to additional gain from the selected provenance that was accumulated in the amount of gain calculated in the present study. The gain by selected provenance of Papua New Guinea and Queensland-Australia for $A$. mangium was reported to be ranging from around $20 \%$ to $40 \%$ for stand volume (Hardiyanto et al., 2000; Nirsatmanto et al.,

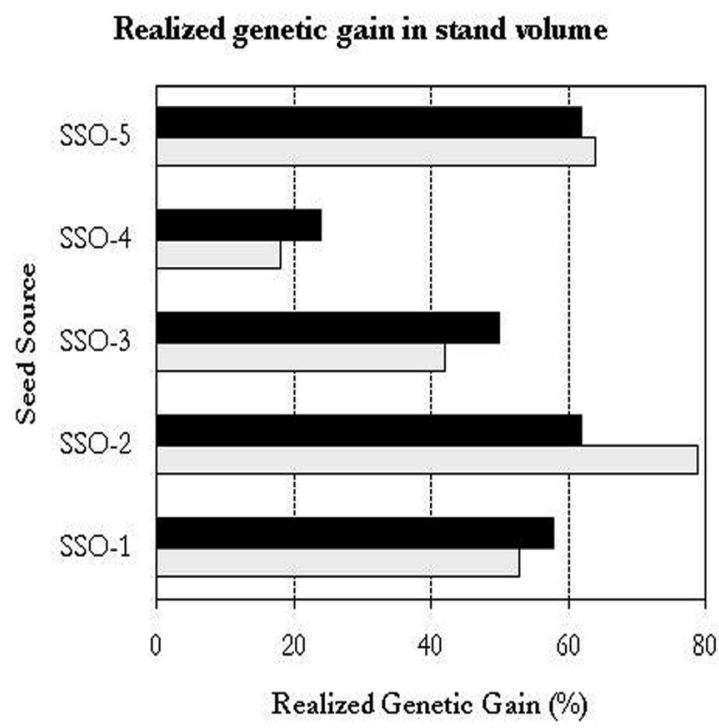

Figure 1. Realized genetic gain (\%) for stand volume across the two sites of genetic gain trial of Acacia mangium at two years age (white bar) and four years age (dark bar) 

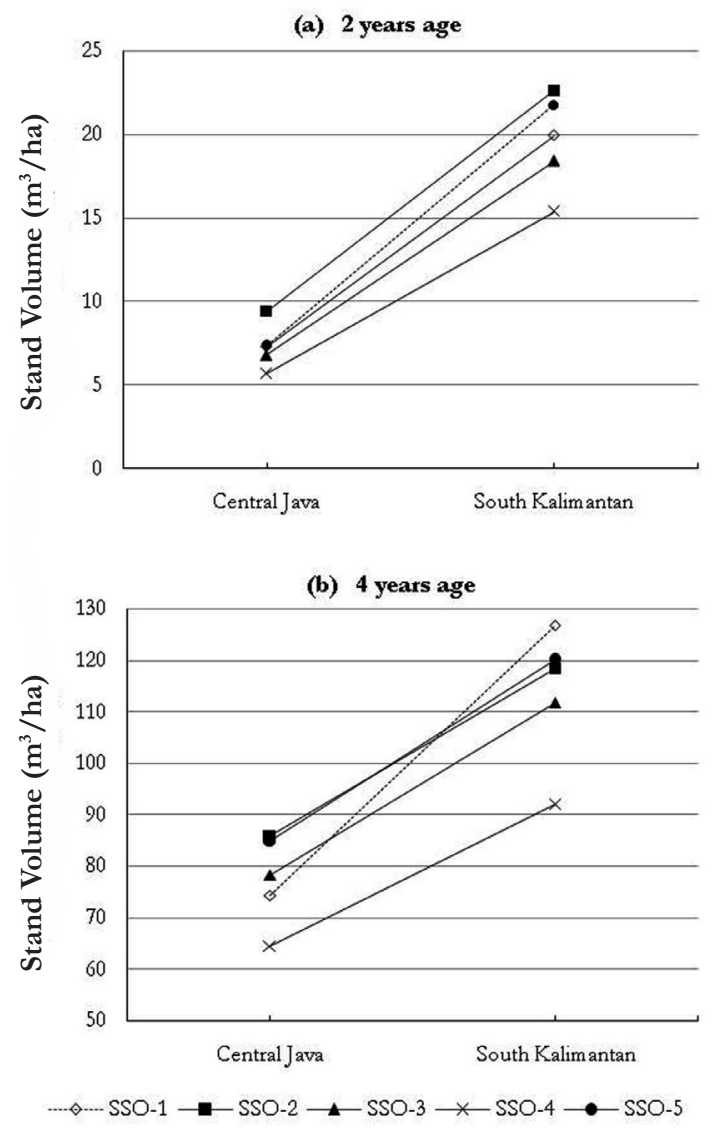

Figure 2. Ranking order of five seedling seed orchard (SSO) between two sites (Central Java and

South Kalimantan) for stand volume observed at 2 years age (a) and 4 years age (b)

2003). Total realized genetic gain by the firstgeneration seed orchard as confirmed by this study was also higher as compared to other studies in pines species, e.g. 16\%-18\% increase in stand volume at 10 years age (Matziris, 1974) and $7 \%-12 \%$ at rotation age ( $\mathrm{Li}$ et al., 2000) for loblolly pine; $32 \%$ increase in individual stem volume for black pine (Matziris, 2005).

Selection of the productive provenance has become an important step for the success of the tree improvement of $A$. mangium. Butcher et al. (1998) has reported major differences in the level of genetic diversity of $A$. mangium in populations from the south of the species range (Daintree, Queensland) compared to levels in populations from Papua New Guinea using RFLPs. Higher level of genetic diversity, as shown by the population of Papua New Guinea $(\mathrm{He}=0.16-0.21)$, tended to produce superior growth in field trial.

\section{Seed Source $x$ Site Interaction}

Analysis of variance across the two sites showed that differences among seed sources were statistically significant for stand volume (Table 5). The average of pooled stand volume from the two sites by seed sources ranged from $9.35 \mathrm{~m}^{3} /$ ha to $16.75 \mathrm{~m}^{3} / \mathrm{ha}$ and from $61.58 \mathrm{~m}^{3} / \mathrm{ha}$ to $99.83 \mathrm{~m}^{3} / \mathrm{ha}$ for two years and four years respectively, with the average values of control (seed stand) were always the lowest (Table 6). Therefore, the realized genetic gain based on across site analysis ranged from 18\% to $79 \%$ at two years, and from $24 \%$ to $62 \%$ at four years (Figure 1). SSO-1, SSO-2 and SSO5 which originated from PNG provenances were consistently found at the top three highest realized genetic gain with a slight change in the ranking order among them between the two sites at four years (Figure 2b). The positive realized genetic gain from all of the five 
orchards through two types of analysis, single analysis (Table 3) and across site analysis (Table 6 ), suggested that the superiority of the five seedling seed orchards were evident for stand volume productivity.

Despite the fact that both sites were considerably different in climate and geographic coordinates, seed source $\mathrm{x}$ site interaction was not significantly different (Table 5), indicating there was not a strong $\mathrm{GxE}$ interaction among the two sites at seed source level. It means that at half rotation age, superiority of the five seedling seed orchards were consistent across the two sites of genetic gain trial for stand volume. This result supports our previously reported study where GxE interaction between South Sumatra and South Kalimantan was not strong to cause any apparent reduction in genetic gain (Nirsatmanto et al., 2004). Thus, improved seed produced from the five seedling seed sources could be deployed into two tested sites of plantations without any serious change of order in their superiority.

The seed source $\mathrm{x}$ site interaction was slightly lower at two years than at four years, as demonstrated by the difference in changing of the ranking order (Figure $2 \mathrm{a}$ and Figure $2 \mathrm{~b}$ ). At two years, all five seeding seed orchards performance was relatively stable across the two sites, while at four years there was one seed source (SSO-1), which most responsive to the site difference. However this interactive effect was not so strong to appear as a significant seed source $\mathrm{x}$ site interaction. SSO-1 which is located in close distance from the trial site in South Kalimantan tended to be more productive for stand volume at older age when planted in a site that pronounced a similar environment, while SSO-2 and SSO-5 was relatively stable across the diverse environment.

The non significance of $\mathrm{GxE}$ interaction at the level of seed sources as resulted in this study was not in agreement with the report of previous GxE interaction study at the level of family (Setyaji, 2011). In the previous study, high significance of family $\mathrm{x}$ site interaction for growth traits were observed using data from second-generation of progeny test of $A$. mangium in South Sumatra and South Kalimantan. This discrepancy might be due to the difference in magnitude of variations, where the increases of genetic variation tend to reduce the strength of $\mathrm{GxE}$ interaction. The five seedling seed orchards in this study were converted from progeny trials which were established using grouped sub-line system based on the original of natural population distribution. It is well known that genetic variation between populations for $A$. mangium was larger than the variation among individuals (family) within the population (Butcher et al., 2000). Among some GxE interaction studies summarized by King (1964) it was also concluded that as the genetic diversity of material increases, the relative magnitude of the interaction decreases.

Result in this study through analysis in realized genetic gain and seed source $\mathrm{x}$ site interaction as described above suggested that genetic improvement in stand volume of A. mangium has been achieved through firstgeneration seedling seed orchards. Selection of productive provenance proved to be an essential factor to bring some amount of improvement from first-generation breeding program for $A$. mangium. This study revealed that seed orchards which were established using family originating from superior provenances of PNG and FNQ consistently produced higher productive stand as compared to the unimproved material.

\section{CONCLUSION}

Realized genetic gains of five seedling seed orchards from first-generation breeding program of $A$. mangium were well verified at half rotation age in genetic gain trials established at two different sites. The genetic gains were high in relation to the stand volume productivity, although the magnitude varied depending on site quality and the age of the stand. Gain observed in poor site quality (Central Java) tended to be higher than that observed in high site quality (South Kalimantan). Across the two sites, the realized genetic gains were in the 
range of $18 \%-79 \%$ at two years of age and $24 \%-62 \%$ at four years of age. Seedling seed orchards consisting of family originating from superior provenance (PNG) showed higher genetic gain. The effect of interaction between seed sources and sites was also weak which indicated that the superiority of improved seed was consistent across the two different sites. The results of the study implied that the genetically improved seed would increase stand volume productivity of $A$. mangium plantations and it could be potentially deployed in wider range of environments without any serious change of order in their superiority.

\section{REFERENCES}

Butcher, P. A., Moran, G. F., \& Perkins, H. D. (1998). RFLP diversity in the nuclear genome of Acacia mangium. Heredity, 81, 205-213.

Eldridge, K. G. (1982). Genetic improvements from a radiata pine seed orchard. New Zealand Journal of Forest Science, 12, 404-411.

Golani, G. D., Siregar, S. T. H., \& Gafur, A. (2009). Tree improvement and silviculture research progress at PT Riau Andalan Pulp Paper APRIL group - challenges and opportunities. In A. Rimbawanto, F. Febrianto \& T.E. Komar (Eds.), Proceedings International Seminar Research on Plantation Forest Management: Challenges and Opprtunities. Bogor, Indonesia, 5 - 6 November 2009 (pp. 21-31). Bogor: Center for Plantation Forest Research and Development.

Hai, P. H., Harwood, C., Kha, L. D., Pinyopusarerk, K., \& Thinh, H. (2008). Genetic gain from breeding Acacia auriculiformis in Vietnam. Journal of Tropical Forest Science, 20(4), 313-327.

Hardiyanto, E. B., Siregar, S. T. H., Wahyono, R., \& Rokhim, M. (2000). The result of provenance trial of Acacia mangium at 5.5 years old in Setuntung (in Indonesian) (Technical Notes) (pp. 1-5). PT Musi Hutan Persada.

Hardiyanto, E. B., \& Wicaksono, A. (2008). Interrotation site management, stand growth and soil properties in Acacia mangium plantations in South Sumatra, Indonesia. In E. K. Nambiar (Ed.), Workshop proceeding, Piracicaba, Brazil, 22-26 November 2004 and Bogor, Indonesia, 6-9 November 2004 (pp. 107-122). Bogor: Center for International Forestry Research (CIFOR).

Harwood, C. E., \& Williams, E. R. (1991). A review of provenance variation in growth of Acacia mangium. In L. T. Carron \& K. M. Aken (Eds.), Breeding Technologies for Tropical Acacias: Proceeding of a Workshop beld in Tawau, Sabah, Malaysia, 1-4 July 1991 (ACIAR Proceeding 37) (pp. 22-30).

Hashimoto, K., Kurinobu, S., \& Suhaendi, H. (1996). Establishment of seed sources of tropical tree species in Indonesia. In M. J. Dieters, A. C. Matheson, D. G. Nikles, C. E. Harwood, \& S. M. Walker (Eds.), Tree improvement for sustainable tropical forestry. Proceeding of the QFRI-IUFRO Conference, Caloundra, Australia. 27 October - 1 November 1996 (pp. 370-371).

Inose, M., Saridi, Z., \& Nakamura, T. (1992). Growth analysis of Acacia mangium. Hoppo Ringyo, 2, 17-19.

Kari, T., Otsamo, A., Kuusipalo, J., Vuokko, R., \& Nikles, G. (1996). Effect of provenance variation and singling and pruning on early growth of Acacia mangium Willd. plantation on Imperata cylindrica (L.) Beauv. dominated grassland. Forest Ecology and Management, 84, 241-249.

Kha, L. D., Harwood, C. E., Kien, N. D., Baltunis, B. S., Hai, N. D., \& Thinh, H. H. (2011). Growth and wood basic density of acacia hybrid clones at three locations in Vietnam. New Forests, 43(1), 13-29.

King, J. P. (1964). Seed source $\mathrm{x}$ environment interaction in Scotch pine: I. Height growth. Silvae Genetica, 14(4), 105-115.

Li, B., McKeand, S. E., \& Weir, R. J. (2002). Impact of forest genetics on sustainable forestry-results from two cycles of loblolly pine breeding in U.S. Journal of Sustainable Forestry, 14(1), 131-144.

Luangviriyasaeng, V., \& Pinyopusarerk, K. (2002). Genetic variation in second-generation progeny trial of Acacia auriculiformis in Thailand. Journal of Tropical Forest Science, 14(1), 131-144.

Mackey, M. (1996). Acacia mangium: an important multipurpose species tree for the tropic lowlands. FACT Sheet 96-03.

Matziris, D. (1974). Predicted versus realized genetic gain in loblolly pine (Pinus taeda L.) improvement (Ph.D Thesis). North Carolina State University.

Matziris, D. (2005). Genetic variation and realized genetic gain from Black pine tree improvement. Silvae Genetica, 54(3), 96-104.

Nirsatmanto, A., Kurinobu, S., \& Hardiyanto, E. B. (2003). A projected increase in stand volume of introduced provenances of Acacia mangium in seedling seed orchards in South Sumatra, Indonesia. Journal of Forest Research, 8, 127-131.

Nirsatmanto, A., Leksono, B., Kurinobu, S., \& Shiraishi, S. (2004). Realized genetic gain 
observed in second-generation seedling seed orchards of Acacia mangium in South Kalimantan, Indonesia. Journal of Forest Research, 9, 265-269.

Otsamo, A., Adjers, G., Hadi, T. S., Kuusipalo, J., Tuomela, K., \& Vuokko, R. (1995). Effect of site preparation and initial fertilization on the establishment and growth of four plantation tree species used in reforestation of Imperata cylindrica (L.) Beauv. dominated grasslands. . Forest Ecology and Management, 73, 271-277.

Otsamo, A. O., Nikles, D. G., \& Vuokko, R. H. O. (1996). Species and provenance variation of candidate acacias for afforestation of Imperata cylindrica grasslands in South Kalimantan, Indonesia. In M. J. Dieters, A. C. Matheson, D. G. Nikles, C. E. Harwood, \& S. M. Walker (Eds.), Tree improvement for sustainable tropical forestry: Proceeding of the QFRI-IUFRO Conference, Caloundra, Australia. 27 October - 1 November 1996. (pp. 46-50).

Setyaji, T. (2011). Genetic × Environment interaction on the second-generation (F-2) of Acacia mangium Willd., breeding seed orchard in four locations in Sumatera and Kalimantan(in Indonesian) (Thesis). Gadjah Mada University.

St. Clair, J. . (1993). Evaluating realized genetic gains from tree improvement. In H. E. Burkhart, T. G. Gregoire, \& J. . Smith (Eds.), Modeling stand response to silvicultural practices: Proceeding of the IUFRO S4.01 Conference, Blacksburg, Virginia, USA. 27 September - 1 October 1993 (pp. 145157).

Werren, M. (1991). Plantation development of Acacia mangium in Sumatra. In J. W. Turnbull (Ed.), Advances in tropical acacia research: proceeding of workshop beld in Bangkok, Thailand. 11-15 February 1991 (ACLAR Proceeding 35) (pp. 107109).

Zobel, B. J., \& Talbert, J. (1984). Applied forest tree improvement (p. 505). New York: John Wiley \& Sons. 